\title{
Exploring Student Academic Procrastination Based on Time Management, Social Support and Self-Efficacy
}

\author{
M. Rudi Irwansyah ${ }^{1 *}$ Made Ary Meitriana ${ }^{1}$ Ni'matul Istiqomah ${ }^{2}$
}

\author{
${ }^{l}$ Economic Education Study Program, Universitas Pendidikan Ganesha, Singaraja, Indonesia \\ ${ }^{2}$ Economic Education Study Program, Universitas Negeri Malang, Malang, Indonesia \\ *Corresponding author.Email: rudi.irwansyah@undiksha.ac.id
}

\begin{abstract}
The purpose of this study was to see how time management, social support and self-efficacy affected students at the Faculty of Economics in Singaraja's academic procrastination. This was causal research with a qualitative approach. This study consisted of independent variables, namely time management, self-efficacy, and social support, and dependent variable, namely academic procrastination. The population was the students of the Faculty of Economics in Singaraja, totalling 366 students. Proportionate stratified random sampling was used as the sampling technique. Questionnaires were used to collect data for the research. Data analysis was conducted by applying a t-test and F-test. Based on the study's findings, time management, self-efficacy, and social support all had significant negative effects on students in the Economic Education Study Program in Singaraja's academic procrastination.
\end{abstract}

Keywords: Academic Procrastination, Time Management, Self-efficacy, Social Support.

\section{INTRODUCTION}

Education is an essential aspect that is important in shaping attitude, behavior, individual and group character. Education is defined as systematically arranged and planned actions to develop an individual's talents and potentials through learning to produce individuals with independent and superior character, which is essential for them to live in the society [1]. Education activities, particularly learning, generally take place in formal education levels; one of which is higher education or universities.

Higher education is a place where students study based on their interests. As students, their main job is to study. In addition, they are also active in various student organizations and participate in other programs in campus aiming to develop their soft skills. Therefore, they have to be able to effectively manage time, be independent and responsible for their obligation, such as completing their academic tasks and finishing their study a timely. However, students may also have bad habits of postponing their tasks. This behavior of postponing tasks by students is known as procrastination.

Procrastination is a special term used to explain an accepted tendency of postponing works. It can be to postpone starting or completing the tasks [2]. Students' academic procrastination is a severe problem with serious implications [3]. Procrastination can also be defined as an action of postponing something intentionally and excessively, that is done by an individual in a certain amount of time [4]. In the academic domain, postponement is often called academic procrastionation. Procrastination in academic scope is seen as a failure in someone's attempt in completing his/her academic tasks within the expected time frame [5]. While according to [6], Academic procrastination interpreted as the unreasonable habit of delaying the start or completion of an academic work. This delay could be due to their academic achievement not aligning with their stated objectives [7], [8].

Academic procrastination frequently happens to students, especially at the university level. In their research, [9] found that $75 \%$ of the respondents procrastinated, and $50 \%$ of them said that they procrastinated constantly and saw it as an issue. Moreover, [10] also found out as many as $70 \%$ of the respondents in his study procrastinated. Students often procrastinate as they perceive their learning assignments incorrectly that they have an irrational mind [11]. Several studies since 1977 have shown that procrastination will always happen to students to any degree [7].

There are several factors lead to students' academic procrastination. [2] categorize them into two; external and internal factors. Internal factors are those that originate from within the students, such as their physical and psychological health., which include students' physical and psychological conditions. The 
psychological condition is claimed to give a greater contribution to students' academic procrastination [12]. External factors are those that originate from outside students, such as their parents' parenting styles and the condition of the environment, such as social factors from the students' closest people.

One of the internal variables that contribute to academic procrastination is time management. [13]. In line with that, according to [14], individuals who procrastinate fail in their time management. Time management is the organization and management of time in carrying out certain jobs effectively and efficiently [15]. Good time management is needed by students to manage the available time and determine priorities in doing their academic tasks. Good time management also enables them to be more focused and well-directed in following the timetable that has been set previously and no time will be wasted.

In addition to time management, self-efficacy is also considered as a part of internal factors that is claimed to lead to academic procrastination. This is supported by the statement of [16] which states that the extent of one's self-efficacy will affect his/her academic procrastination. Self-efficacy is one of the motivation expectancies components in education, and it describes how confident a participant gets in his or her ability to complete a task but not many students understand their self-efficacy [17], [18]. The better a person understands his as well as her self-efficacy, the better he or she will do in the learning process [19], [20]. This shows that self-efficacy is very influential on a person's performance in carrying out the learning process, as well as the completion of his tasks.

In line with that opinion, according to [21], academic procrastination that happens to students can be caused by their self-efficacy. Self-efficacy is someone's personal judgment of how well his/her efforts and potentials can be in performing his/her tasks to reach his/her goals [22]. Self-efficacy is a part of self-knowledge, which has an important role in someone's daily life [2]. Therefore, a student's self-efficacy should be high. The higher one's self-efficacy, the lower the intention of doing academic procrastination will be [23]. Self-efficacy also has an important role in determining the extent of a student's effort is facing a difficult challenge, for example when working on academic tasks. When a student is confident with his/her ability, it will be easier for him/her to complete a task. He/she will be able to solve the obstacles that he/she faces. On the other hand, if a student's self-efficacy is low, he/she will not be confident with his/her ability in working on his/her academic tasks, and as a result, he/she will procrastinate.

Social support is one of the external factors that contribute to academic procrastination. Social support is one of the most dominant factors that can lead to academic procrastination [24]. In line with that statement, [21] states that social support will lower students' tendency to do academic procrastination. Social support is defined as attention, appreciation, assistance, and comfort given by someone [25]. Social support can be from parents, siblings, peers, or anybody around us. Academic procrastination can be reduced through social support from family, friends, and school [3]. Every social support that someone gets from his/her surrounding will help him/her in finding solutions to the problems that he/she encounters so that he/she will keep on trying [11]. Thus, it can be said that social factors can help and encourage students' spirit to keep trying and working hard in doing their academic tasks so they will not postpone their works.

The phenomenon of academic procrastination that the researcher found happened to Economic Education Study Program students in Singaraja. The results of the researcher's observation on the students revealed the reasons that made them procrastinate their academic tasks repeatedly. They are as follows: (1) students thought that the deadline given to complete an assignment was far so they chose to postpone; (2) students prioritized fun activities, such as playing with their gadgets, over academic assignments; (3) lack of students' understanding and confidence in working on the assignments, laziness and not knowing where to start (4) students tended to do their assignments overnight as according to them, ability and ideas in working on the assignments emerge when they approached deadlines.

\section{METHOD}

This study was causal research with a quantitative approach. Causal research is a cause and effect research. Therefore, this study had independent and dependent variables. The independent variables were time management $\left(\mathrm{X}_{1}\right)$, self-efficacy $\left(\mathrm{X}_{2}\right)$, and social support $\left(\mathrm{X}_{3}\right)$, while the dependent variable was academic procrastination. The objective of this research was to see how time management, self-efficacy, and social support affected academic procrastination. The population was the students of Economic Education in Singaraja, totaling 366 students. One hundred and ninety-one students were chosen as samples. Slovin's formula is used to determine this number. The sample in each stratum was determined using the proportional stratified random sampling technique.

Documentation and questionnaires were used as data gathering strategies in this study. Documentation was used to gain data on the number of students in Economic Education. Questionnaires were used to contain statements based on the indicators of each variable to obtain data or information regarding time management, self-efficacy, social support, and academic procrastination. Before the questionnaire was given to the respondents, to find out the validity of the statements and their reliability as a measuring tool, validity and reliability tests were done first. 
The techniques of data analysis applied in this study were classical assumption and statistical hypothesis tests. The classical assumption test was done using SPSS Statistic version 24 that consisted of 1) normality test, done to both the data of independent and dependent variables, to find out their normality; 2) multicollinearity test (if there is no correlation between the independent variables, the regression model is considered good); 3) heteroscedasticity test, which was done using Glejser test; 4) linearity test, which was done to find out whether there was a linear correlation between the independent and dependent variables. Afterward, the hypothesis test was done assisted by SPSS Statistic version 24 that consisted of t-test and Ftest. The t-test was done to test the partial effect of the independent variables on the dependent variable. Whereas F-test was done to test the effect of the independent variables on the dependent variable simultaneously.

\section{RESULT AND DISCUSSION}

The first hypothesis was to see if time management could reduce academic procrastination among students in Singaraja's Economic Education Study Program. The results of the analysis can be seen in table 1. Based on table 1 , the $t_{\text {count }}$ was $-12,351$ with significance value $0,000<0,05$ so $\mathrm{H}_{0}$ was rejected. As a result, it may be inferred that time management has a major detrimental impact on academic procrastination. The negative influence of variable $\mathrm{X} 1$ on variable $\mathrm{Y}$ indicates that the better the students' time management, the lesser their academic procrastination, and vice versa.

The second hypothesis was to test the efects on academic procrastination among students in Singaraja's Economic Education Study Program. The results of the hypothesis can be seen in table 2 . Based on table 2 , $t_{\text {count }}$ was $-10,481$ with significance value $0,000<0,05$ so $\mathrm{H}_{0}$ was rejected. Then it could be concluded that there was a significant negative effect of self-efficacy on academic procrastination. The negative effect of variable $\mathrm{X}_{2}$ on variable $\mathrm{Y}$ means that the higher the self-efficacy of the students, the lower their academic procrastination would be and vice versa.

The third hypothesis was to prove the effectiveness of social support on the academic procrastination of the students of the Economic Education Study Program in Singaraja. The results of the analysis can be seen in table 3 . Based on table 3 , the $t_{\text {count }}$ was $-10,079$ with significance value $0,000<0,05$, so $\mathrm{H}_{0}$ was rejected. It could be concluded that there was a negative effect of variable $\mathrm{X}_{3}$ on variable $\mathrm{Y}$, which means that the higher the social support, the lower the academic procrastination of the students would be and vice versa.

The fourth hypothesis was to show the effects of time management, self-efficacy, and social support on the academic procrastination of students in the
Economic Education Study Program's. The results of the analysis can be seen in table 4 . Based on table 4 , the $F_{\text {count }}$ was 67,963 with significance value $0,000<0,05$ so $\mathrm{H}_{0}$ was rejected. It means that time management, selfefficacy, and social support all had a significant impact on academic procrastination among students in Singaraja's Economic Education Study Program.

According to the findings of the investigation, time management has a considerable detrimental impact on academic procrastination. The negative effect indicated that greater time management would result in less academic procrastination. The findings of a prior study backed up this conclusion, According to [26] who also stated that time management and academic procrastination had a significant negative association. A similar opinion was stated by [13], it found that time management has a significant negative impact on academic procrastination. This study stated that good time management was one of the important factors that students must have to lower the intention to postpone academic assignments, such as the assignments they got in their lectures.

The ability to manage time helps students in managing their time and in selecting priority assignments so that they can work more focused and finish their works timely. In optimizing time management skills, students as early as possible will have to get used to setting goals and priorities, making plans and arranging schedules for every activity, managing time allotment, using time efficiently as well as being consistent in implementing time management in working on their academic tasks.

The analysis of the second hypothesis showed that there was a significant negative effect of self-efficacy on academic procrastination. This means that the higher the self-efficacy of the students, the lower the academic procrastination would be. On the other hand, the lower the self-efficacy, the higher the academic procrastination would be. This is in line with [22] who stated that students with low self-efficacy tended to postpone their academic assignments, while students with high selfefficacy did not. This is also supported by research by [27] which stated that there was a considerable negative correlation between self-efficacy and academic procrastination. 
Table 1. The result of a t-test to see how time management affects academic procrastination.

\begin{tabular}{|c|c|c|c|c|c|c|}
\hline \multicolumn{7}{|c|}{ Coefficients ${ }^{a}$} \\
\hline \multirow{2}{*}{\multicolumn{2}{|c|}{ Model }} & \multicolumn{2}{|c|}{ Unstandardized Coefficients } & \multirow{2}{*}{$\begin{array}{l}\text { Standardized } \\
\text { Coefficients } \\
\text { Beta }\end{array}$} & \multirow[t]{2}{*}{$\mathrm{t}$} & \multirow[t]{2}{*}{ Sig. } \\
\hline & & B & Std. Error & & & \\
\hline \multirow[t]{2}{*}{1} & (constant) & 103,481 & 3,700 & & 23,826 &, 000 \\
\hline & Time Management &,- 496 & ,040 &,- 668 & $-10,481$ &, 000 \\
\hline
\end{tabular}

Table 2. The result of a t-test to see how self-efficacy affects academic procrastination.

\begin{tabular}{|c|c|c|c|c|c|c|}
\hline \multicolumn{7}{|c|}{ Coefficientsa } \\
\hline \multirow{2}{*}{\multicolumn{2}{|c|}{ Model }} & \multicolumn{2}{|c|}{ Unstandardized Coefficients } & \multirow{2}{*}{$\begin{array}{l}\text { Standardized } \\
\text { Coefficients } \\
\text { Beta }\end{array}$} & \multirow[t]{2}{*}{ t } & \multirow[t]{2}{*}{ Sig. } \\
\hline & & B & Std. Error & & & \\
\hline \multirow[t]{2}{*}{1} & (constant) & 103,404 & 4,340 & & 23,826 &, 000 \\
\hline & Self-efficacy & $-1,245$ & , 119 &,- 606 & $-10,481$ &, 000 \\
\hline
\end{tabular}

Table 3. The result of a t-test to see how social support affects academic procrastination.

\begin{tabular}{|c|c|c|c|c|c|c|}
\hline \multicolumn{7}{|c|}{ Coefficientsa } \\
\hline \multirow{2}{*}{\multicolumn{2}{|c|}{ Model }} & \multicolumn{2}{|c|}{ Unstandardized Coefficients } & \multirow{2}{*}{$\begin{array}{l}\text { Standardized } \\
\text { Coefficients } \\
\text { Beta }\end{array}$} & \multirow[t]{2}{*}{$\mathrm{t}$} & \multirow[t]{2}{*}{ Sig. } \\
\hline & & B & Std. Error & & & \\
\hline \multirow[t]{2}{*}{1} & (constant) & 101,487 & 4,323 & & 23,478 &, 000 \\
\hline & Social Support & $-1,149$ &, 114 &,- 591 & $-10,079$ &, 000 \\
\hline
\end{tabular}

Table 4. The result of a t-test to see how the student's time management, self-efficacy, and social support affects academic procrastination.

\begin{tabular}{|c|c|c|c|c|c|c|}
\hline \multicolumn{7}{|c|}{ ANOVAa $^{a}$} \\
\hline \multicolumn{2}{|c|}{ Model } & Sum of Squares & Df & Mean Square & F & Sig. \\
\hline \multirow[t]{3}{*}{1} & Regression & 15284,734 & 3 & 5094,911 & 67,963 &, $000^{b}$ \\
\hline & Residual & 14018,721 & 187 & 74,966 & & \\
\hline & Total & 29303,455 & 190 & & & \\
\hline \multicolumn{7}{|c|}{ a. Dependent Variable: Academic Procrastination } \\
\hline \multicolumn{7}{|c|}{ b. Predictors: (Constant), Social Support, Time Management, Self-Efficacy } \\
\hline
\end{tabular}

Students with high self-efficacy are confident with the knowledge and ability that they have. This will invoke their motivation so that they can control situations and actions when working on their tasks, reach their goals, and deal with challenges in fulfilling their academic obligations. Good self-efficacy will also help students in evaluating themselves and realizing their potentials and weaknesses. In optimizing self-efficacy, students have to be able to decide and try to do challenges that they think they are capable of, have faith to encourage themselves to become more persistent and manage to do things independently.

Based on the results of the third hypothesis, it was discovered that social support had a negative effect on academic procrastination. This means that the higher the social support, the lower the academic procrastination 
would be. This is in line with what had been stated by [9] that an important external factor that had been suggested to lower students' procrastination was social support. This statement is supported by a study by [28] and [3] which stated that there was a significant negative correlation between social support and academic procrastination.

The findings of this study indicated that social support had an important role in lowering students' academic procrastination. Therefore, a student has to be able to build a good relationship with his/her family, peers, close friends, and the other people around him/her. A good relationship with other people will bring comfort to students as they will feel that other people are attentive to them, appreciate them and care about them. A good relationship will become a positive reward for them. Students will be able to get assistance, helps, suggestions, and directions from their surroundings. This is in line with what has been stated by [11] that social support can help someone to find solutions to the obstacles that he/she faces.

Based on the result of the fourth hypothesis, it was found out that simultaneously, there was an effect of time management, self-efficacy, and social support on academic procrastination. This is in line with [2] and [29] that stated that Two factors influenced academic procrastination; internal and external factors. First, internal factors, that came from within someone and included time management and self-efficacy. This is supported by the statement by [13] that stated that time management was one of the internal factors that affected academic procrastination. This is also supported by the research result of [30] that stated that self-efficacy was one of the factors that led to academic procrastination. Second, external factors, that are the factors that came from outside someone; one of which was social support. This is supported by [31] and [3] who stated that social support was one of the external factors that affected academic procrastination.

\section{CONCLUSION}

Based on the results, it can be concluded that time management has a considerable negative impact on students' academic procrastination. Self-efficacy has a strong negative impact on students' academic procrastination. Students' academic procrastination was also significantly influenced by social support. Simultaneously, time management, self-efficacy, and social support all had a significant impact on students' academic procrastination.

Based on the conclusion drawn, a few suggestions can be proposed to some parties. First, for students. Academic procrastination can give bad effects. Therefore, students will have to get used to managing time well as early as possible. They have to believe in their ability and have a good relationship with other people to gain social support and avoid procrastinating in fulfilling their academic obligations.

Second, for other researchers. The results of this study add information on the effect of time management, self-efficacy, and social support on academic procrastination. It is hoped that future researchers can conduct research in a wider scope and add or use different variables related to the factors that affect academic procrastination.

Third, for Undiksha. It is expected that Undiksha can give information or insight for students regarding the negative effects of academic procrastination and the benefits of good time management, self-efficacy, and social support for students through various programs, such as seminars, general lectures, and socialization. In addition, it is expected that the library will provide more books about academic procrastination as references for students.

\section{REFERENCES}

[1] H. Purnomo, Psikologi Pendidikan. Yogyakarta: LP3M UMY, 2019.

[2] M. N. Ghufron and R. S. Risnawita, Teori-Teori Psikologi. Yogyakarta: Ar-Ruzz Media, 2016.

[3] A. Madjid, D. A. Sutoyo, and S. F. Shodiq, "Academic procrastination among students: The influence of social support and resilience mediated by religious character," Cakrawala Pendidik., vol. 40, no. 1, pp. 56-69, 2021.

[4] J. J. Reza, Manage Your Time for Success: Cerdas Mengelola Waktu untuk Mencapai Sukses. Yogyakarta: ANDI, 2010.

[5] A. Pala, M. Akyildiz, and C. Bağci, "Academic procrastination behaviour of pre-service teachers' of Celal Bayar University," Procedia - Soc. Behav. Sci., vol. 29, pp. 1418-1425, 2011.

[6] F. L. Yong, "A Study on the Assertiveness and Academic Procrastinations of English and Communication Student at a Private University," Am. J. Sci. Res., no. 9, pp. 62-72, 2010.

[7] V. Day, D. Mensink, and M. O’Sullivan, "Patterns of academic procrastination," J. Coll. Read. Learn., vol. 30, no. 2, pp. 120-134, 2000.

[8] H. C. Schouwenburg, "Academic Procrastination," in Procrastination and Task Avoidance, 1995, pp. 71-96.

[9] J. B. Burka and L. M. Yuen, Why You Do It, What To Do About It Now. Cambridge: Da Capo Press, 2008.

[10] S. Muyana, "Prokrastinasi Akademik Dikalangan 
Mahasiswa Program Studi Bimbingan dan Konseling," Couns. J. Bimbing. dan Konseling, vol. 8, no. 1, pp. 45-52, 2018.

[11] I. Nurmala, Mewujudkan Remaja Sehat Fisik, Mental dan Sosial (Model Intervensi Health Educator for Youth). Surabaya: Airlangga University Press, 2020.

[12] U. Candra, M. E. Wibowo, and N. Setyowani, "Faktor-Faktor Penyebab Prokrastinasi Akademik Pada Siswa Kelas XI SMA NEGERI KABUPATEN TEMANGGUNG," Indones. $J$. Guid. Couns., vol. 3, no. 3, pp. 66-72, 2014.

[13] M. R. Irwansyah and P. D. Asrida, "Does Time Management and Peer Management Affect The Academic Procrastination Of Students?," Int. J. Res. Innov. Soc. Sci., vol. V, no. I, pp. 318-322, 2021.

[14] J. W. Santrock, Educational psychology, 6th ed., Sixth. New York: McGraw-Hill Education, 2016.

[15] M. D. Mulyani, "Hubungan Antara Manajemen Waktu Dengan Self Regulated Learning Pada Mahasiswa," Educ. Psychol. J., vol. 2, no. 1, pp. 43-48, 2013.

[16] N. Hidayah and A. Atmoko, Landasan Sosial Budaya dan Psikologis Pendidikan: Terapannya di Kelas. Malang: Gunung Samudera, 2014.

[17] P. R. Pintrich and E. V. De Groot, "Motivational and self-regulated learning components of classroom," J. Educ. Psychol., vol. 82, no. 1, pp. 33-40, 1990.

[18] F. Pajares, "Self-efficacy beliefs in academic settings," Rev. Educ. Res., vol. 66, no. 4, pp. 543578, 1996.

[19] M. Rashtchi, "Self-efficacy and critical thinking of novice and experienced EFL teachers: A sequential mixed methods study," Pertanika J. Soc. Sci. Humanit., vol. 29, no. 1, pp. 1-25, 2021.

[20] C.-H. Chen and N. T. T. Phan, "Development of the Self-efficacy Beliefs of Engineering Undergraduates Preparing for an International Contest," Pertanika J. Soc. Sci. Humanit., vol. 29, no. 2, pp. 819-837, 2021.

[21] K. Amelia and Hadiwinarto, "Hubungan Antara Dukungan Sosial Dengan Prokrastinasi Akademik Siswa Pada Kelas X IPS Di SMA Negeri 2 Mukomuko," J. Ilm. BK Cons., vol. 3, no. 1, pp. 19, 2020
[22] Triyono and M. E. Rifai, Efikasi Diri dan Regulasi Emosi dalam Mengatasi Prokrastinasi Akademik. Sukoharjo: CV. Sindunata, 2018.

[23] H. P. H. Chow, "Procrastination Among Undergraduate Students: Effects of Emotional Intelligence, Efficacy," Alberta J. Educ. Res., vol. 57, no. 2, pp. 234-240, 2011.

[24] A. R. Hakim and N. Widyarini, "Effect Of Social Support and Confidence to Procrastination in The End Of Level Students Faculty X," Int. J. Res. Prublications, vol. 16, no. 1, pp. 2-15, 2018.

[25] E. P. Sarafino and T. W. Smith, Health Psychology:Biopsychosocial Interactions, Seventh Ed. United States of America: Libray of Congress Cataloging, 2011.

[26] G. Ocak and S. Boyraz, "Examination of the Relation between Academic Procrastination and Time Management Skills of Undergraduate Students in Terms of Some Variables," J. Educ. Train. Stud., vol. 4, no. 5, pp. 76-84, 2016.

[27] Z. Ozer and R. Yetkin, "Walking through different paths: Academic self-efficacy and academic procrastination behaviors of pre-service teachers," J. Lang. Linguist. Stud., vol. 14, no. 2, pp. 89-99, 2018.

[28] P. A. Lumbantobing, "Hubungan Adversity Quptient dan Dukungan Sosial Dengan Prokrastinasi Akademik Dalam Penyelesaian Skripsi Pada Mahasiswa yang Bekerja Di PTS STMIK-STIE MIKROSKIL Medan," J. Mutiara Pendidik. Indones., vol. 10, no. 8, pp. 1-14, 2016.

[29] F. Abdul, H. A. Kader, \& Mourad, and A. Eissa, "The Effectiveness of Time Management Strategies Instruction on Students' Academic Time Management and Academic Self-efficacy," Int. J. Psycho-Educational Sci., vol. 4, no. 1, pp. 44-50, 2015.

[30] M. Wulandari, S. K. Umaroh, and S. E. Mariskha, "Pengaruh Efikasi Diri Dan Kontrol Diri Terhadap Prokrastinasi Akademik Pada Mahasiswa Universitas 17 Agustus 1945 Samarinda," Motiv. J. Psikol., vol. 3, no. 1, pp. 35-43, 2020.

[31] S. Pradinata and J. D. Susilo, "Prokrastinasi Akademik dan Dukungan Sosial Teman Sebaya pada Mahasiswa Fakultas Psikologi Universitas Katolik Widya Mandala Surabaya," J. Exp. (Jurnal Psikol. Indones., vol. 4, no. 2, pp. 85-95, 2016. 